\title{
The effectiveness of using zeolite in the processing of spring wheat seeds
}

\author{
Kamila Garafutdinova ${ }^{l *}$, Gulnara Rakhmanova ${ }^{l}$, Elena Prishchipenko ${ }^{l}$ and Lilia Gaffarova ${ }^{2}$ \\ ${ }^{1}$ Tatar Research Institute of Agricultural Chemistry and Soil Science of FRC Kazan Scientific Center of RAS, 420059 Kazan, Republic \\ of Tatarstan, Russia \\ ${ }^{2}$ Kazan State Agrarian University, 420015 Kazan, Republic of Tatarstan, Russia
}

\begin{abstract}
The article presents the results of vegetation studies on dusting the seeds of agricultural crops with zeolite. The experiment used seeds of spring wheat variety Ulyanovskaya-105 and mechanically activated zeolite of the Tatar-Shatrashansk deposit of the Republic of Tatarstan. The activated zeolite was obtained by mechanical activation using a crushing and screening plant at OAO Zeolites of the Volga Region, the particle size is $0.20 \mathrm{~mm}$. The effect of dusting seeds with zeolite in various doses $(25 \mathrm{~kg} / \mathrm{t}, 50$ $\mathrm{kg} / \mathrm{t}, 75 \mathrm{~kg} / \mathrm{t}$, and $100 \mathrm{~kg} / \mathrm{t}$ ) on the growth and development of spring wheat plants, as well as on the quality indicators of grain, has been evaluated. The results revealed a positive effect of agro mineral on such parameters as seed germination (increase by $2.0-12.0 \%$ ), chlorophyll content in plants in the tillering phase (by 7.4-33.3\%), as well as on morphometric and biochemical parameters - plant height (by $2.5 \%-10.1 \%$ ), the number of grains in the ear (by $7.7 \%$ ), plant biomass (by $1.7 \%-7.9 \%$ ) and the protein content in the grain (by $0.6-4.2 \%$ ).
\end{abstract}

\section{Introduction}

Every year, the issue of increasing crop yields while maintaining soil fertility in conditions of intensive farming becomes more and more urgent. With a significant pesticide load on the soil and the irrational use of its resources, it is important to find both economically profitable and environmentally friendly methods to ensure high plant productivity. One of these methods, which have great potential for widespread use in agriculture, is the use of mineral raw materials, in particular zeolites and zeolite-containing rocks.

Zeolites are a group of framework aluminosilicate minerals capable of ion exchange and adsorption [1]. The Russian Federation (RF) has rich reserves of mineral raw materials. The largest deposits of the Russian Federation are in the Oryol, Kemerovo, and Sakhalin regions, the Republics of Tatarstan (RT) and Sakha, the Trans-Baikal, Krasnoyarsk, and Khabarovsk regions. The total natural reserves of zeolites in the Russian Federation are estimated at 23.8 billion tons [2].

All zeolite deposits in the Republic of Tatarstan are compactly located in the Drozhzhanovsky region and are confined to the Ulyanovsk-Saratov zeolite-bearing region. The largest of the deposits is TatarskoShatrashanskoye, the explored reserves of which are about 100 million tons, and the projected reserves are 300-400 million tons.

The use of zeolites in agriculture is determined by their special properties - a high capacity of cation exchange, the ability to sorption and reverse dehydration, as well as the presence in the composition of nutrients, in particular, silicon in an accessible form, which has a beneficial effect on the growth and development of cultivated plants $[3,4,5]$. In agriculture, it is important to use zeolites as plant growth stimulants, chemical ameliorants, and prolongers of mineral fertilizers [4]. The work of L.M. Bikkinina et al. found a positive effect on the quantitative and qualitative indicators of potatoes when processing seed tubers with natural zeolites [6].

One of the main cultivated grain crops in the crop rotation of the Russian Federation is spring wheat. Its sown area in 2020 amounted to 12.6 million hectares. The gross grain harvest reached 85.9 million tons [7]. The development of methods for increasing the productivity of this crop is of great industrial importance, in this regard, the purpose of the experiment was to study the effect of zeolite on the growth and development of spring wheat.

\section{Materials and research methods}

The object of the study was the seeds of spring wheat cultivar Ulyanovskaya-105, previously powdered with zeolite, fraction $0.20 \mathrm{~mm}$. Experiment scheme: 1) control; 2) background - N60P60K60; 3) background + dusting of zeolite seeds at a dose of $25 \mathrm{~kg} / \mathrm{t} ; 4$ ) background + dusting of zeolite seeds at a dose of 50 $\mathrm{kg} / \mathrm{t}$; 5) background + dusting of zeolite seeds at a dose of $75 \mathrm{~kg} / \mathrm{t}$; 6) background + dusting of zeolite seeds at a

*Corresponding author: amiliamilka24@gmail.com 
dose of $100 \mathrm{~kg} / \mathrm{t}$. The activated zeolite was obtained by mechanical activation using a crushing and screening plant at OAO Zeolites of the Volga Region [8].

The chemical composition of the zeolite of the Tatarsko-Shatrashansky deposit of the Republic of Tatarstan,\%: $\mathrm{SiO} 2$ - 56.8, including in the amorphous state - 26.7, $\mathrm{Al} 2 \mathrm{O} 3$ - 5.4, Fe2O3 - 2.3, $\mathrm{CaO}$ - 14.9, $\mathrm{MgO}$ - 1.3, Na2O - 0.1, K2O - 1.2, P2O5 - 0.1 Mineral composition,\%: clinoptilolite - 20.0-30.0, montmorillonite - 20.0-30.0, opal-cristobalite - 28.036.7, calcite - 10.6-21.0, quartz - 4.6-11.3 [3, 9]. According to the classification of chemical compounds, zeolite is a low-hazard substance and belongs to the 4th hazard class.

The studies were carried out based on the growing house of the Tatar Scientific Research Institute of Agrochemistry and Soil Science - a separate structural unit of the Federal Research Center of the KazSC RAS, the analytical replication was threefold. The plants were grown in Wagner vessels with an area of $0.018 \mathrm{~m} 2$. A gray forest soil of medium loamy granulometric composition was used as a substrate. Agrochemical characteristics of the soil: organic matter content $-3.2 \%$ (low), pHsalt - 6.2 units. (neutral reaction of the environment), hydrolytic acidity - $1.7 \mathrm{meq} / 100 \mathrm{~g}$ of soil (neutral), the sum of absorbed bases according to the Kappen method - $24.2 \mathrm{meq} / 100 \mathrm{~g}$ of soil (high), the content of alkaline hydrolyzable nitrogen according to Cornfield - $96.6 \mathrm{mg} / \mathrm{kg}$ (low), mobile forms of phosphorus and potassium - 231 and $201 \mathrm{mg} / \mathrm{kg}$, respectively (high content of both elements).

Before sowing, as a background, a complex mineral fertilizer was applied to Azofosk (NPK content $16: 16: 16)$ at the rate of $0.725 \mathrm{~g}$ per vessel. Soil moisture during the growing season of plants was maintained artificially by regular weighing and watering within 70$75 \%$ of the total field moisture capacity.

In the experiment, the germination of seeds on the 7th day, morphometric and biochemical parameters of spring wheat plants, as well as agrochemical and microbiological analyzes of the soil were studied at the end of the growing season.

The chlorophyll content in plant samples in the tillering phase was determined by the accelerated method according to V. A. Razumov [10].

The respiratory activity of the soil microbial community was assessed according to ISO 16072, 2002 [11]. Microbial biomass was calculated based on substrate-induced respiratory activity following ISO 14240-1, 1997 [12].

Microbial biomass ( $\mathrm{mg} / \mathrm{kg}$ soil) was calculated using the formula:

$$
\mathrm{X}=40 \mathrm{R}+0.37 \text { (1) }
$$

where $\mathrm{X}$ is the concentration of microbial carbon in the soil, $\mathrm{mg} / \mathrm{kg} ; \mathrm{R}$ is the rate of release of substrate-induced $\mathrm{CO} 2$, in $\mathrm{ml}$ per $\mathrm{kg}$ per hour.

Statistical processing of research results was performed according to B.A. Dospekhov by the method of analysis of variance using the Microsoft Office Excel 2010 software [13].

\section{Research results}

Seed germination is one of the most important indicators for assessing the future harvest. The germination capacity of spring wheat when dusting with zeolite in the experimental variants was 72.0-92.0\% (Table 1).

Table 1.Seed germination of spring wheat on the 7th day

\begin{tabular}{|l|c|}
\hline \multicolumn{1}{|c|}{ Option } & Germination, $\%$ \\
\hline Control (noprocessing) & 56.0 \\
\hline Background $\mathrm{N}_{60} \mathrm{P}_{60} \mathrm{~K}_{60}$ & 80.0 \\
\hline Background + dusting of seeds with zeolite at a dose of $25 \mathrm{~kg} / \mathrm{t}$ & 72.0 \\
\hline Background + dusting of seeds with zeolite at a dose of $50 \mathrm{~kg} / \mathrm{t}$ & 92.0 \\
\hline Background + dusting of seeds with zeolite at a dose of $75 \mathrm{~kg} / \mathrm{t}$ & 82.0 \\
\hline Background + dusting of seeds with zeolite at a dose of $100 \mathrm{~kg} / \mathrm{t}$ & 74.0 \\
\hline LSD $_{0.5}$ & 4.80 \\
\hline
\end{tabular}

The highest values were observed in variants with zeolite treatment at doses of 50 and $75 \mathrm{~kg} / \mathrm{t}-92.0$ and $82.0 \%$, respectively. Germination increased by $2.0-$ $12.0 \%$ compared to the background variant.

The chlorophyll content is one of the most important ecological and physiological indicators for assessing the impact of environmental factors on plant growth and development [14]. The chlorophyll content in wheat plants in the control was $2.5 \mathrm{mg} / \mathrm{kg}$, in the background $2.7 \mathrm{mg} / \mathrm{kg}$ (Table 2).
The data obtained revealed a positive effect of dusting seeds with zeolite in two variants - using a dose of $25 \mathrm{~kg} / \mathrm{t}$ (chlorophyll content $-2.9 \mathrm{mg} / \mathrm{kg}$ ) and $100 \mathrm{~kg} / \mathrm{t}$ $(3.6 \mathrm{mg} / \mathrm{kg})$. The indicator increased relative to the background by $7.4 \%$ and $33.3 \%$, respectively.

The treatment of seeds with zeolite influenced the morphometric parameters of plants. In the variants of the experiment, there is an increase in such indicators as plant height, the number of grains in an ear, plant biomass, and root mass (Table 3). 
Table 2.Chlorophyll content in spring wheat plants

\begin{tabular}{|c|l|c|}
\hline № & \multicolumn{1}{|c|}{ Option } & Chlorophyllcontent, $\mathrm{mg} / \mathrm{kg}$ \\
\hline 1 & Control (noprocessing) & 2.5 \\
\hline 2 & Background ${ }_{60} \mathrm{P}_{60} \mathrm{~K}_{60}$ & 2.7 \\
\hline 3 & Background + dusting of seeds with zeolite at a dose of $25 \mathrm{~kg} / \mathrm{t}$ & 2.9 \\
\hline 4 & Background + dusting of seeds with zeolite at a dose of $50 \mathrm{~kg} / \mathrm{t}$ & 2.4 \\
\hline 5 & Background + dusting of seeds with zeolite at a dose of $75 \mathrm{~kg} / \mathrm{t}$ & 2.3 \\
\hline 6 & Background + dusting of seeds with zeolite at a dose of $100 \mathrm{~kg} / \mathrm{t}$ & 3.6 \\
\hline \multicolumn{2}{|c|}{ LSD $_{0.5}$} & 0.36 \\
\hline
\end{tabular}

Table 3.Morphometric parameters of spring wheat plants

\begin{tabular}{|l|c|c|c|c|c|}
\hline \multicolumn{1}{|c|}{ Option } & $\begin{array}{c}\text { Plantheight, } \\
\mathrm{cm}\end{array}$ & Earlength, cm & $\begin{array}{c}\text { Number of } \\
\text { grains per ear, } \\
\text { pcs }\end{array}$ & $\begin{array}{c}\text { Plantbiomass, } \\
\mathrm{g}\end{array}$ & Rootweight, g \\
\hline Control & 57.7 & 5.6 & 14.6 & 16.3 & 1.90 \\
\hline Background & 63.2 & 6.4 & 15.5 & 17.7 & 1.90 \\
\hline $\begin{array}{l}\text { Background + dusting of seeds } \\
\text { with zeolite at a dose of 25 kg / }\end{array}$ & 69.6 & 6.4 & 16.7 & 18.0 & 1.35 \\
\hline $\begin{array}{l}\text { Background + dusting of seeds } \\
\text { with zeolite at a dose of 50 kg / t }\end{array}$ & 68.6 & 6.2 & 15.6 & 17.5 & 1.35 \\
\hline $\begin{array}{l}\text { Background + dusting of seeds } \\
\text { with zeolite at a dose of 75 kg / t }\end{array}$ & 64.8 & 5.9 & 12.3 & 17.7 & 1.80 \\
\hline $\begin{array}{l}\text { Background + dusting of seeds } \\
\text { with zeolite at a dose of 100 kg / t }\end{array}$ & 65.4 & 5.9 & 15.2 & 19.1 & 2.65 \\
\hline \multicolumn{1}{|c|}{$\mathrm{LSD}_{0.5}$} & 4.13 & 0.77 & 1.34 & 0.57 & 0.40 \\
\hline
\end{tabular}

The height of plants treated with zeolite exceeded the indicator in the background variant by $1.6-6.4 \mathrm{~cm}(2.5-$ $10.1 \%)$. The most significant increase in the indicator compared to the background was recorded in the variant with dusting at a dose of $25 \mathrm{~kg} / \mathrm{t}$.

The variant with the use of a dose of $25 \mathrm{~kg} / \mathrm{t}$ was distinguished by the highest content of grains in the ear 16.7 pieces, which is $7.7 \%$ more than in the background.

Dusting seeds at doses of 25 and $100 \mathrm{~kg} / \mathrm{t}$ had a positive effect on plant biomass. The increase was $0.3 \mathrm{~g}$ (1.7\%) and $1.4 \mathrm{~g}(7.9 \%)$, respectively.

A significant increase in root weight was observed in the variant with treatment at a dose of $100 \mathrm{~kg} / \mathrm{t}$. The increase amounted to $0.75 \mathrm{~g}(39.5 \%)$ against the background value.

At the same time, the treatment of seeds with zeolite did not affect the length of the ear of spring wheat.

In addition to quantitative indicators, qualitative characteristics are also of great importance.

Protein is the most important indicator of the technological and nutritional value of grain [15]. The protein content in the grain of spring wheat according to the variants of the experiment varied within 10.6-16.9\% (Table 4).

The use of zeolite for dusting helped to improve the quality of wheat grain for this indicator. The highest value was obtained when using a dose of $25 \mathrm{~kg} / \mathrm{t}$ of zeolite: the increase in comparison with the background was $4.2 \%$.Presowing treatment with zeolite did not have a significant effect on the chemical composition of the grain - the content of total nitrogen, phosphorus, and potassium. The content of total nitrogen according to the variants of the experiment was $2.0-3.0 \%$, phosphorus $0.2-0.4 \%$, potassium - $0.6-0.7 \%$.

The microbiological activity of the gray forest soil in terms of basal respiration and microbial biomass was assessed at the end of the growing season (Table 5). These indicators are significant ecological and physiological indicators reflecting the activity of the microbial community [16].

Basal respiration indices were 12.7 and $18.7 \mathrm{mg}$ $\mathrm{CO} 2 / 100 \mathrm{~g} * 24$ in the control and background variants, respectively. In variants with zeolite, an increase in activity was found in basal respiration, $\mathrm{CO} 2$ emissions were 21.1-24.4 $\mathrm{mg} \mathrm{CO} 2 / 100 \mathrm{~g} * 24$. The maximum indicator of respiratory activity was obtained during the pre-sowing treatment of seeds with zeolite at a dose of $75 \mathrm{t} / \mathrm{ha}-24.4 \mathrm{mg} \mathrm{CO} 2 / 100 \mathrm{~g} * 24$, which is 1.9 times higher than the control, and 1.3 times higher than the background.

The content of microbial biomass in the control was $31.0 \mathrm{mg} \mathrm{Cmic} / \mathrm{g}$, in the background variant $-45.2 \mathrm{mg}$ $\mathrm{Cmic} / \mathrm{g}$. The use of zeolite promoted an increase in the microbial biomass 1.6-1.9 times compared to the control, 1.1-1.3 times - to the background. The highest value of the indicator - $59.2 \mathrm{mg} \mathrm{Cmic/g}$ was found during the presowing treatment of seeds with zeolite at a dose of 100 t/ha.At the end of the growing season, the study carried out agrochemical analyzes of the soil. It studied such indicators as the content of organic matter, $\mathrm{pH}$ of the salt extract, hydrolytic acidity, the number of absorbed bases, the content of alkaline hydrolysable nitrogen, mobile forms of phosphorus, and exchangeable potassium (Table 6). 
Table 4.Biochemical parameters of spring wheat grain.

\begin{tabular}{|c|c|c|c|c|}
\hline Option & Protein, $\%$ & $\begin{array}{l}\text { Mass fraction of } \\
\text { total nitrogen, } \%\end{array}$ & $\begin{array}{l}\text { Mass fraction of } \\
\text { total } \\
\text { phosphorus, } \%\end{array}$ & $\begin{array}{c}\text { Mass fraction of } \\
\text { total } \\
\text { potassium, } \%\end{array}$ \\
\hline Control & 10.6 & 2.0 & 0.4 & 0.7 \\
\hline Background & 12.7 & 2.3 & 0.4 & 0.7 \\
\hline $\begin{array}{l}\text { Background + dusting of seeds } \\
\text { with zeolite at a dose of } 25 \mathrm{~kg} / \mathrm{t}\end{array}$ & 16.9 & 3.0 & 0.3 & 0.6 \\
\hline $\begin{array}{l}\text { Background + dusting of seeds } \\
\text { with zeolite at a dose of } 50 \mathrm{~kg} / \mathrm{t}\end{array}$ & 16.6 & 3.0 & 0.3 & 0.7 \\
\hline $\begin{array}{l}\text { Background + dusting of seeds } \\
\text { with zeolite at a dose of } 75 \mathrm{~kg} / \mathrm{t}\end{array}$ & 14.0 & 2.6 & 0.2 & 0.7 \\
\hline $\begin{array}{l}\text { Background + dusting of seeds } \\
\text { with zeolite at a dose of } 100 \mathrm{~kg} / \mathrm{t}\end{array}$ & 13.3 & 2.4 & 0.2 & 0.6 \\
\hline $\mathrm{LSD}_{0.5}$ & 0.42 & 0.28 & 1.34 & 0.11 \\
\hline
\end{tabular}

Table 5.Basal respiration and microbial biomass

\begin{tabular}{|l|c|c|}
\hline \multicolumn{1}{|c|}{ Option } & Basal respiration, $\mathrm{mg} / 100 \mathrm{~g} * 24 \mathrm{~h}$ & Microbial biomass, $\mathrm{mg} / 100 \mathrm{~g} * \mathrm{~h}$ \\
\hline Control & 12.7 & 31.0 \\
\hline Background & 18.7 & 45.2 \\
\hline $\begin{array}{l}\text { Background + dusting of seeds with } \\
\text { zeolite at a dose of 25 kg / t }\end{array}$ & 22.1 & 49.9 \\
\hline $\begin{array}{l}\text { Background + dusting of seeds with } \\
\text { zeolite at a dose of 50 kg / t }\end{array}$ & 23.6 & 50.4 \\
\hline $\begin{array}{l}\text { Background + dusting of seeds with } \\
\text { zeolite at a dose of 75 kg / t }\end{array}$ & 24.4 & 57.1 \\
\hline $\begin{array}{l}\text { Background + dusting of seeds with } \\
\text { zeolite at a dose of 100 kg / t }\end{array}$ & 21.1 & 59.2 \\
\hline \multicolumn{1}{c}{$\mathrm{LSD}_{0.5}$} & 0.36 & 0.34 \\
\hline
\end{tabular}

Table6.Agrochemical indicators of soils

\begin{tabular}{|c|c|c|c|c|c|c|c|}
\hline Option & Humus, $\%$ & $\mathrm{pH}_{\mathrm{sol}}$ & $\begin{array}{c}\mathrm{Hr} \\
\mathrm{mEq} / 100 \mathrm{~g}\end{array}$ & $\begin{array}{l}\mathrm{S}_{\mathrm{PO}}, \mathrm{mg}- \\
\mathrm{eq} / 100 \mathrm{~g}\end{array}$ & $\begin{array}{c}\text { Nalkali., } \\
\mathrm{mg} / \mathrm{kg}\end{array}$ & $\begin{array}{l}\mathrm{P}_{2} \mathrm{O}_{5} \\
\mathrm{mg} / \mathrm{kg}\end{array}$ & $\begin{array}{l}\mathrm{K}_{2} \mathrm{O} \\
\mathrm{mg} / \mathrm{kg}\end{array}$ \\
\hline Control & 3.2 & 6.2 & 1.7 & 24.2 & 96.6 & 231 & 201 \\
\hline Background & 3.1 & 6.2 & 2.8 & 24.0 & 98.0 & 373 & 357 \\
\hline $\begin{array}{l}\text { Background + dusting of } \\
\text { seeds with zeolite (fr. 0- } \\
0.20 \mathrm{~mm}) 25 \mathrm{~kg} / \mathrm{t}\end{array}$ & 3.1 & 6.3 & 1.9 & 25.4 & 98.0 & 311 & 307 \\
\hline $\begin{array}{l}\text { Background + dusting of } \\
\text { seeds with zeolite (fr. 0- } \\
0.20 \mathrm{~mm}) 50 \mathrm{~kg} / \mathrm{t}\end{array}$ & 2.9 & 6.3 & 1.8 & 24.2 & 91.0 & 301 & 270 \\
\hline $\begin{array}{l}\text { Background + dusting of } \\
\text { seeds with zeolite (fr. 0- } \\
0.20 \mathrm{~mm}) 75 \mathrm{~kg} / \mathrm{t}\end{array}$ & 3.1 & 6.2 & 1.8 & 24.4 & 95.2 & 324 & 278 \\
\hline $\begin{array}{l}\text { Background + dusting of } \\
\text { seeds with zeolite (fr. 0- } \\
0.20 \mathrm{~mm}) 100 \mathrm{~kg} \mathrm{/} \mathrm{t}\end{array}$ & 3.1 & 6.2 & 2.0 & 23.6 & 88.2 & 333 & 286 \\
\hline $\mathrm{LSD}_{0.5}$ & 0.30 & 0.04 & 0.25 & 0.27 & 0.68 & 5.0 & 4.84 \\
\hline
\end{tabular}


Zeolite did not significantly affect most of the indicators. However, a significant difference was revealed between the reaction of the soil medium in the background (6.2 units) and variants with zeolite treatment at doses of 25 and $50 \mathrm{~kg} / \mathrm{t}-6.3$ units. There is also a decrease in the content of alkaline hydrolysable nitrogen, mobile forms of phosphorus, and exchangeable potassium. This is probably due to the sorption of excess nutrients by the zeolite.

\section{Conclusion}

The results of the experiment showed a positive effect of pre-sowing treatment of seeds with zeolite on germination (hereinafter, the increase to the background value was $2.0 \%-12.0 \%$ ), chlorophyll content $(7.4 \%$ $33.3 \%)$, and growth parameters - plant height $(2.5 \%$ $10.1 \%)$, the number of grains in an ear $(7.7 \%)$ and plant biomass $(1.7 \%-7.9 \%)$. Dusting the seeds promoted an increase in the amount of protein in the grain - by $4.2 \%$ concerning the background.

Thus, the dusting of seeds of spring wheat variety Ulyanovskaya-105 promoted an increase in germination, stimulation of plant growth processes, and an increase in the quality indicators of grain in growing conditions. The work was carried out within the framework of State Assignment No. FMEG-2021-0003, registration number 121021600147-1.

\section{References}

1. C. Sangeetha, P.Baskar, Agricultural Review, 37, 101 (2016)

2. K.K. Razmakhnin, A.N. Khatkova, Modern technologies for processing and modification of zeolite-containing rocks of Eastern Transbaikalia (Transbaikal State University, Chita, 2014)

3. S.A. Aliev, T.K. Ishkaev, A.K. Yapparov, Scientific substantiation of the use of local agricultural ore as fertilizer in agriculture of the Middle Volga region (Kazan Center for Innovative Technologies, 2009)
4. L.L. Ubgunov, Agrochemical mineral raw materials: natural zeolites(Publishing house of BNTs SB RAS, Ulan-Ude, 2012)

5. S.A.A. Nakhli, M.Delkash, B.E. Bakhshayesh, H. Kazemian, Water Air Soil Pollution, p. 228 (2017)

6. L. Bikkinina, V. Ezhkov, E. Prishchipenko, M. Jarullin, Impact of Multiple Forms and Application Methods of Natural Zeolite on Potato Yield Increase, Proceedings of the International Scientific Conference The Fifth Technological Order: Prospects for the Development and Modernization of the Russian Agro-Industrial Sector (2020)

7. Russian statistical yearbook. Statistical collection (Rosstat, Moscow, 2020)

8. Production and sale of zeolites from the producer Zeolites of the Volga region. Retrieved from: https://zeol.ru/ceolit-aktivirovannyy.

9. A.V. Yakimova (ed.), Agromineral resources of Tatarstan and prospects for their use (Feng, Kazan, 2002)

10. V.A. Razumov, The chemist's guide to feed analysis (Rosselkhozizdat, Moscow, 1986)

11. ISO 16072:2002, Soil quality - Laboratory methods for determination of microbial soil respiration(2002) $19 \mathrm{p}$.

12. ISO 14240-1:1997, Soil quality - Determination of soil microbial biomass. Part 1: Substrate induced respiration method(1997) $4 \mathrm{p}$.

13. B.A. Dospekhov, Field experiment methodology (with the basics of statistical processing of research results) (Kolos, Moscow, 1965)

14. E.M. Yahia, Fruit and Vegetable Phytochemicals. Chemistry and Human Health, 2nd Edition. Chlorophylls: Chemistry and Biological Functions (2017)

15. G. Rakhmanova, L.Bikkinina, E. Prishchipenko, M. Muratov,Vladimisky zemledelets, 3, 30 (2020)

16. A. Vershinin, A.Petrov, R.Juranets-Luzhaeva, T.Kuznetsova, R.Khabibullin, Bulletin of Kazan Technological University, 20(4), 103 (2017) 